\title{
$\bullet$ \\ Structural Analysis and Evaluation of Antimicrobial Activity of Camellia sinensis Aqueous Extract
}

\section{IJCRR}

Section: Healthcare

ISI Impact Factor

(2019-20): 1.628

IC Value (2019): 90.81

$\operatorname{SJIF}(2020)=7.893$

(c) (i) (8)

Copyright@IJCRR

\section{Devadharshini R' ${ }^{1}$, Charulatha S', Arunava Das'2, J. Bindhu ${ }^{3}$}

'Third year B. Tech Biotechnology students, Department of Biotechnology, Bannari Amman Institute of Technology, Sathyamangalam, Erode District, Tamil Nadu, India; ${ }^{2}$ Associate professor, Department of Biotechnology, Bannari Amman Institute of Technology Sathyamangalam-638401, Erode District, Tamil Nadu, India; ${ }^{2}$ sssistant Professor, Department of Biotechnology, Bannari Amman Institute of Technology, Sathyamangalam, Erode District, Tamil Nadu, India.

\section{ABSTRACT}

Introduction: The study is focused to determine the properties (antimicrobial, antioxidant, anticancer and phytochemical) of the Camellia sinensis. In this study the extract of Camellia sinensis performed to assess the antimicrobial potential against skin associated microorganisms. Antioxidant activity performed in the plant Camellia sinensis play a protective major role in different types of cancer, heart diseases and stroke.

Objective: To identify the rich components present in green tea leaves aqueous extract by phytochemical methods and then it is useful as drug for various human effects and problems.

Methods: The tea leaves extract was subjected to phytochemical tests, Gas chromatography-mass spectroscopy (GC-MS), Fourier transform infrared spectroscopy (FTIR) analysis and antimicrobial test. Phytochemical analysis of Green tea leaves (Camellia sinensis) was performed and the result showed that the presence of phenolic compounds (alkaloids, flavonoids, steroids, triterpenoids and tannins). Antimicrobial property was performed with two different gram-positive and gram-negative bacteria.

Result: Laboratory studies shows that herbs like Camellia sinensis (green tea leaves) can be effectively used in curing bleeding, mental health, regulate body temperature, healing wounds, and to aid digestion. It also shows positive impact on types of cancer such as breast cancer, bladder cancer, ovarian cancer, skin cancer and so on.

Conclusion: Camellia sinensis are rich in flavonoids, caffeine and catechins. The tea leaves extract possesses an excellent antimicrobial, antioxidant property which can be used as an alternative drug of choice due to its lower side-effects to human.

Key Words: Camellia Sinensis, Leaves Extract, GC-MS, FTIR, Cancer

\section{INTRODUCTION}

Green tea leaves scientific name is Camellia sinensis which is evergreen species, originated from China. They are native to southeast and east India but nowadays tea leaves are growing both in tropic and subtropic regions. Height of tea shrub is 9 meters and it will grow up to 5 to 10 meters in length. They are dark in colour with pointed tips and serrated edges. These tea leaves contain alkaloid mainly caffeine, which is present in tea or coffee and it is a stimulant of the central nervous system. ${ }^{1}$ Tea leaves are rich in antioxidants. ${ }^{2}$ The antioxidant compound present in it has anti-inflammatory, antitumor, antibacterial, antiviral, antiangiogenic, antimutagenic, anticarcinogenic activities. ${ }^{2,3}$ As it contains nutrients, it helps in the release of nutrients to the soil and it makes the environment a nutrient-rich one and makes the soil health- ier. ${ }^{4}$ Though the tea leaves are rich in tannic acid they are used as good fertilizer and helps in treating sunburns. ${ }^{5}$ They help freshen our breath and after some processing, it is used to soothe our skin after some wounds which will reduce the inflammation and keep the skin healthier. ${ }^{2}$ They can also be used for the removal of unpleasant smell and to reduce bug bites. $^{6}$

Green tea leaves belong to kingdom Plantae. Its order is Ericales. It comes under the family called Theaceae. Its genus is Camellia. And its species is C. sinensis. It contains catechins, polyphenolic compounds which give protective effects on the cardiovascular system. It helps in reducing cholesterol levels and also improves the ratio of the good cholesterol (HDL) to bad cholesterol (LDL), as well as it helps in curing diabetes, weight loss, inflammatory bowel disease and

\section{Corresponding Author:}

Dr. J. Bindhu, Assistant Professor, Department of Biotechnology, Bannari Amman Institute of Technology, Sathyamangalam, Erode District, Tamil Nadu, India, Email: bindhu@bitsathy.ac.in.

ISSN: 2231-2196 (Print)

Received: 08.06 .2020
ISSN: 0975-5241 (Online)

$$
\text { Revised: } 26.09 .2020
$$

Accepted: 18.10 .2020
Published: 03.02 .2021 
iron overload. It may lower blood pressure and even reduce the risk of stroke and coronary heart diseases. ${ }^{7}$ Tea leaves reduce the effects of cancer by inhibiting the growth of cancer cells. ${ }^{3,7}$ And even protect brain cells from oxidative stress as it contains antioxidants in it. Even helps in lowering the blood sugar levels. ${ }^{8}$ Also helpful in rheumatoid arthritis, even in infection and impaired immune functions., ${ }^{9,10,11}$ They contain polyphenols which include flavonoids(major), phenolic acids and flavanols. Major flavonoid of green tea leaves is catechins. ${ }^{12}$ Most significant active compound is Epigallocatechin Gallate (EGCG). EGCG is the most powerful antioxidant in it as well as it inhibits the growth of cancer cells without harming the healthy tissues. ${ }^{13}$ Catechins are described by the presence of a benzopyran structure which has at least one aromatic ring in it due to antioxidant and anti-inflammatory properties. ${ }^{14-17}$ EGCG acts as an immune modulator, effective in neurological problems and reduces the risk of chronic diseases. ${ }^{17}$ Consumption of green tea increases the mineral density of bones and even strengthens the immune system action. It keeps us fresh and reduces our depression. ${ }^{15}$ Lowers the diabetes risk and even burns the fat. ${ }^{18}$ Green tea consumption prevents various types of cancer includes the mouth, stomach, small intestine, and so on. Cell lines have various advantages like easy to use and even cost-effective so only it is used. Cancer cells will be kept on dividing and even it is growing over time. Cancer cell lines are used in the research of studying the biology of cancer and even to test cancer treatments.

\section{MATERIALS AND METHODS}

\section{Plant material}

Green tea leaves (Camellia sinensis) is collected from Ooty tea estate and brought to our laboratory. The leaves are torn into small pieces and kept in shadow dry for 48 hours. Then by using mixer the dried leaves are chopped down into a fine powder and it is stored in an airtight container.

\section{Preparation of the leaf extract}

Chopped tea powder of about $5 \mathrm{~g}$ is weighed and kept in a beaker. Then the solvent is added for about $50 \mathrm{~mL}$ of $100 \%$ ethanol into the sample powder. Then Ultrasonicator extraction was done for 20 mins with on pulse 9sec and off pulse $3 \mathrm{sec}$. After the completion of extraction to remove ethanol the extract is kept at $50 \mathrm{C}$ for vapourisation. Then the sample is scrapped and kept in a sample container.

\section{Qualitative phytochemical analysis}

Phytochemical constituents were analysed by presence or absence by using the following procedures:

Test for proteins: Biuret's Test: The Tea extract of $1 \mathrm{ml}$ was added with $1 \mathrm{ml}$ of $4 \% \mathrm{NaOH}$ and $1 \mathrm{ml}$ of $1 \% \mathrm{CuSO} 4$. If the solution colour change to violet or pink colour it indicates the presence of proteins.

Test for Tannin's and Phenols: Ferric Chloride Test: The Tea extract of $1 \mathrm{ml}$ was added with $1 \mathrm{ml}$ of $5 \%$ Ferric Chloride. If the solution colour changes into blue-black or brown-green colour then it indicates the presence of tannins and phenols.

Test for Glycosides: Keller-Killani Test: The Tea extract of $1 \mathrm{ml}$ was added with $0.5 \mathrm{ml}$ of glacial acetic acid, 2 drops of $5 \%$ Ferric Chloride and 2 drops of concentrated Sulphuric acid. Then the disappearance of reddish-brown colour at the junction of two layers and bluish-green in upper layer indicates the presence of cardiac glycosides.

Test for Saponins: Foam Test: The Tea extract of $1 \mathrm{ml}$ was added with $20 \mathrm{ml}$ of water and shaken vigorously. If the persistent foam is observed then it indicates the presence of saponin.

Test for Flavonoids: Alkaline reagent Test: The Tea extract of $1 \mathrm{ml}$ was added with a few drops of $\mathrm{NaOH}$. Then an intense yellow colour will appear and when a few drops of dilute acid is added if it becomes colourless then it indicates the presence of flavonoids.

Test for Triterpenoids: Salkowaski Test: The Tea extract of $1 \mathrm{ml}$ was added with 5 drops of concentrated Sulphuric acid. The appearance of a greenish-blue colour indicates the presence of triterpenoids.

Test for Phlobatannin's: The Tea extract of $1 \mathrm{ml}$ was boiled with $1 \% \mathrm{HCl}$. The occurrence of red precipitate deposition indicates the presence of phlorotannins.

Test for Alkaloids: Mayer's Test: The Tea extract of $1 \mathrm{ml}$ was added with $1 \mathrm{ml}$ of Mayer's reagent (Potassium mercuric iodide). The occurrence of a white precipitate indicates the presence of alkaloids.

Test for Lipids: The Tea extract of $1 \mathrm{ml}$ was added with $0.5 \mathrm{~N}$ alcoholic Potassium hydroxide and a drop of phenolphthalein. Then this mixture of the solution was heated on a water bath for about 1 hour and soap formation or neutralization of alkali indicates the presence of lipids.

Test for Steroids: The Tea extract of $1 \mathrm{ml}$ was added with $2 \mathrm{ml}$ of chloroform and concentrated Sulphuric acid. The upper layer turns into a red and Sulphuric acid layer showed yellow with green fluorescence and it indicates the presence of steroids.

Test for Terpenoids: The Tea extract of $1 \mathrm{ml}$ was added with $1 \mathrm{ml}$ of chloroform and after $5 \mathrm{mins} 1 \mathrm{ml}$ of concentrated Sulphuric acid was added. Then greyish colour indicates the presence of terpenoids.

\section{GC-MS Analysis}


The chemical composition of the floral sample was analysed through gas chromatography-mass spectrometry. The analysis was carried out using GC-MS Perkin Elmer model: Clarus 680 which is equipped with mass spectrometer Clarus 600 (EI) and analysed using Turbo Mass ver 5.4.2 software. A fused silica column which is packed with Elite-5MS (5\% biphenyl $95 \%$ dimethylpolysiloxane, $30 \mathrm{~m} \times 0.25 \mathrm{~mm}$ ID $\times$ $250 \mu \mathrm{m}$ df). To separate the components Helium was used as the carrier gas at a constant flow rate of $1 \mathrm{~mL} / \mathrm{min}$. During the chromatographic run, the temperature of the injector was set at $260^{\circ} \mathrm{C}$. The extracted sample of $1 \mu \mathrm{L}$ was injected into the equipment and the oven temperature were $60^{\circ} \mathrm{C}$ for about 2 minutes followed by $300^{\circ} \mathrm{C}$ at the rate of $10^{\circ} \mathrm{C}$ min- $1 ; \&$ $300^{\circ} \mathrm{C}$ for about 6 mins. The conditions of the mass detector were: transfer line temperature $230^{\circ} \mathrm{C}$; ion source temperature $230^{\circ} \mathrm{C}$ and ionisation mode electron impact at $70 \mathrm{eV}$, a scan time $0.2 \mathrm{sec}$ and scan-interval of $0.1 \mathrm{sec}$. The fragments from 40-600 Da. The spectrum of the components was compared with the database of known components stored in the GC-MS NIST (2008) library.

\section{FTIR Analysis}

Green tea leaves extract was analysed by FTIR method. The extracted sample was taken in the ratio of 1:9 and it was blended with $\mathrm{KBr}$ which was pelletized by $\mathrm{KBr}$ hydraulic press of pressure about 10 tons. FTIR was used to analyse the functional moieties in the pellet at the infrared range of $400-4000 \mathrm{~cm}^{-1}$. The stretching at $3304.44 \mathrm{~cm}^{-1}$ was due to the $\mathrm{C}-\mathrm{H}$ stretching of the alkaloids (Z, Z-6,13-Octadecadien1-ol Acetate) present in the extract. The stretching at 2923.38 $\mathrm{cm}^{-1}$ and $2852.71 \mathrm{~cm}^{-1}$ was due to the aldehyde C-H stretching (6,11-Undecadiene, 1-Acetoxy-3,7-Dimethyl) of the extract. The region from $1700 \mathrm{~cm}^{-1}$ to $1600 \mathrm{~cm}^{-1}$ was due to the $\mathrm{C}=\mathrm{O}$ stretching, the region $1500 \mathrm{~cm}^{-1}$ to $1300 \mathrm{~cm}^{-1}$ was due to the $\mathrm{C}=\mathrm{C}$ and acyl $\mathrm{C}=\mathrm{O}$ stretching. From $1200 \mathrm{~cm}^{-1}$ to $1000 \mathrm{~cm}^{-1}$ indicate the alkoxy C-O stretching present in the extracted compound (1,9-Nonanediol, Dimethanesulfonate). The FTIR result conclude the presence of Z, Z-6,13-Octadecadien-1-ol Acetate, 6,11-Undecadiene,1-Acetoxy-3,7Dimethyl, 6,8-Dodecadien-1-ol(6Z,8E) and 1,9-Nonanediol, Dimethanesulfonate.

\section{Antibacterial assay}

The antibacterial assay of Camellia sinensis was performed with five gram-positive bacteria and two gram-negative bacteria. Gram-positive bacteria such as Bacillus subtilis, Streptococcus agalactiae, Listeria monocytogenes, Staphylococcus aureus, Streptococcus faecalis and gram-negative bacteria such as Escherichia coli, Klebsiella oxytoca, Klebsiella aerogenes by the following agar well diffusion method. The following bacteria were inoculated in the sterile nutrient plates individually by swabbing technique. The wells are made up of diameter mm using the sterile agar well puncher.
Then 5 wells were punched. Then the Tea extract was diluted at different concentrations of $(25 \%, 50 \%, 75 \%, 100 \%)$ using sterile distilled water. Then in the centre, well water and the other four wells, the extract with different concentrations was pipetted into it. Then the agar plates were placed in the incubator at $\pm 37^{\circ} \mathrm{C}$. After 24 hours of incubation the zone of inhibition was measured in $\mathrm{mm}$.

\section{Antioxidant activity}

Antioxidant activity is nothing but the limitation of the oxidation of proteins, lipids, DNA or other molecules which occurs by inhibiting the propagation stage in the oxidation chains. Antioxidant activity of the extract is based on the scavenging of 2,2-diphenyl-1-picrylhydrazyl (DPPH) assay. In this assay different concentrations of both standard and samples (ascorbic acid) were taken and their volume was adjusted to $100 \mu 1$ using methanol. By using methanol as a solvent, the DPPH solution of $0.01 \mathrm{mM}$ was prepared. From the solution prepared mix $3 \mathrm{ml}$ of $0.01 \mathrm{DPPH}$ solution with samples of different concentrations. Prepare negative control by adding $100 \mu 1$ of methanol to the $3 \mathrm{ml}$ of solution. Kept the tube with mixtures to stand in a dark place at room temperature for 30 minutes. After $30 \mathrm{~min}$ utes of the process the shading of the tube with mixtures changes from violet to yellow which shows the presence of cancer-preventing agents. The above evaluation was estimated by its absorbance at $517 \mathrm{~nm}$. For both standard and sample, the IC50 esteem (inhibitory focus) was determined. The of hindrance was determined by utilizing the accompanying recipe

$$
\% \text { of hindrance }=[\mathrm{A} 0-\mathrm{A} 1 / \mathrm{A} 0] * 100
$$

In which A0 is the absorbance of the control (for example DPPH arrangement without test), A1 is the absorbance of the test or on the other hand standard (for example DPPH arrangement with test).

\section{RESULT AND DISCUSSION}

Laboratory studies show that herbs like Camellia sinensis (green tea leaves) can be effectively used in curing bleeding, mental health, regulate body temperature, healing wounds, and to aid digestion. It also shows the positive impact on types of cancer such as breast cancer, bladder cancer, ovarian cancer, skin cancer and so on. Research on Camellia sinensis shows that more amount of polyphenols can kill the cancerous cells and prevent them from their growth. People are taking tea for more health benefits such as to lose their weight, to avoid strokes, to reduce cholesterol, to cure type 2 diabetes, and for inflammatory skin diseases. It is considered as the world's number one health drink and it is rich in the number of antioxidants to prevent cell damage. Even though there are numerous benefits of Camellia sinensis in the pre- 
sent world, future researches and studies need to define the actual magnitude of health benefits.

The phytoconstituents present in the organic extracts were determined qualitatively by HPTLC. The phytochemical studies showed the presence of compounds such as proteins, tannins, phenols, flavonoids, glycosides, lipids, triterpenoids, alkaloids, steroids in aqueous extract or ethanol extract whereas terpenoids, phlorotannin were absent in the ethanol or aqueous extract. The performed results were shown in table 1. The compounds present in Camellia sinensis which are identified by phytochemical studies have antimicrobial, anti-oxidant and anti-bacterial properties in which flavonoids have antioxidant properties. Similar, extraction from herbal leaves results in the antimicrobial activity and antioxidant activity. ${ }^{19,20}$

The components present in the extract which were obtained from the GC-MS results are shown in Table 2. The molecule 21.00 - bicyclo[4.1.0]heptane,7-pentyl- and 20.41-caffeine showed maximum peak followed by 27.77-1,9-nonanediol ,dimethanesulfonate showed highest peak , 20.09-2,7-octadiene-1,6,diol,2,6-dimethyl-,(z)-showed moderate peak and 19.59-z,z-6,13-octadecadien-1-ol acetate showed the lowest peak. Other than the molecule bicyclo [4.1.0] heptane,7pentyl- and 6,8-Dodecadien-1-ol(6Z,8E) all other molecules contain oxygen group. The presence of oxygen may be the reason for the anti-oxidant properties.

To determine whether the floral extract possesses antibacterial activity the antimicrobial properties was been performed. Then to find the antibacterial properties disc diffusion assay was performed. The plates for different types of bacteria were prepared with respective agar. Then the plates were punched with a good puncher. After the wells are ready the samples were prepared in different concentrations like $20 \%$ $50 \% 75 \%$ and $100 \%$ concentrated samples. Then the different concentrated samples were transferred onto the wells of the plate and the zone of inhibition diameter around the wells reveals the antibacterial activity. The clear region around the wells shows that there is no bacterial growth in it and it is the zone of inhibition. Different types of bacterial strains were used to perform the antibacterial activity are Bacillus subtilis, Streptococcus agalactiae, Listeria monocytogenes, Staphylococcus aureus, Streptococcus faecalis, Escherichia coli, Klebsiella oxytoca, Klebsiella aerogenes. Among these strains, Listeria monocytogenes have shown the highest susceptibility in the floral extract. The bacterial species such as Escherichia coli have exhibited moderate susceptibility. The zone of inhibitions of bacterial species is shown (Figure 2).

The sample contains the high number of antioxidants which were indicated by DPPH results. The below Figure 1 is provided with the IC50 values for both the standard (ascorbic acid) and sample (floral extract). The graph reveals the standard has $400.6 \mu \mathrm{g} / \mathrm{ml}$ and the sample has $608 \mu \mathrm{g} / \mathrm{ml}$.
Similarly, few researchers have performed the antimicrobial test on E.coli,A. caliginosaby disc method and the zone of incubation was $100 \mathrm{Au} / \mathrm{mL} .^{20-21}$

\section{CONCLUSION}

The Phytochemical analysis of the green tea leaves indicates the presence of flavonoids, alkaloids, triterpenoids. The antimicrobial activity of the extract shows an effective activity in Listeria monocytogenes of the zone of inhibition at different concentrations. The antioxidant compound in the green tea leaves extract can be used for the chemotherapeutic drug for cancer treatment.

\section{ACKNOWLEDGEMENT}

This research is a part of the B. Tech project work of the first and second authors. Authors gratefully acknowledge AICTE, New Delhi, sponsored Molecular Diagnostics and Biomolecular Characterization Laboratory, Department of Biotechnology and Bannari Amman Institute of Technology.

Declaration of Interest: The authors report no conflicts of interest. Source of funding is nil.

Ethical Clearance: Nil.

Permission To Reproduce: Nil.

\section{REFERENCES}

1. Nagashima, Goto T, Yoshida Y and Kiso M. Simultaneous analysis of individual catechin and caffeine in green tea. J Chromatogr Anal 1996;749(1-2):295-299.

2. Chopade VV, Phatak AA, Upaganlawar AB and Tankar AA. Green tea (Camellia sinensis): Chemistry, Traditional, Medicinal uses and its Pharmacological activities- a review. Pharma Rev 2008; 2(3):157-162.

3. Zaveri NT. Green tea and its polyphenolic catechins: Medicinal uses in cancer and noncancer applications. Life Sci 2006;78(18):2073-2080.

4. Intawongse M and Dean JR. Use of the physiologically-based extraction test to assess the oral bioaccessibility of metals in vegetable plants grown in contaminated soil. Env Pollut 2007;152(1): 60-72.

5. Sedaghathoor S, Torkashvand AM, Hashemabadi D and Kaviani B. Yield and quality response of tea plant to fertilizers. African J Agri Res 2009;4(6):568-570.

6. Utama-Ang N, Kopermsub P, Thakeow P and Samakradhamrongthai R. Encapsulation of Michelia Champaca L. Extractand Its Application in Instant Tea. Int J Food Eng 2017;3(1):48-55.7. Kavitha R, Kamalakannan P, Deepa T, Elamathi R, Sridhar S and Suresh Kumar J. In vitro antimicrobial activity and phytochemical analysis of Indian medicinal plant Couroupita guianensis Aubl. J Chem Pharm Res 2011;3(6):115-121.

7. Nammi, Boini KM, Lodagala SD, and Behara RBS. The juice of fresh leaves of Catharanthus roseus Linn. Reduces blood glucose in normal and alloxan diabetic rabbits. BMC Complemen Altern Med 2003;3(4):1-4. 
8. Sinija VR and Mishra HN. Green tea: Health benefits. J Nut Env Med 2009;17(4):232-242.

9. Schneider C and Segre T. Green Tea: Potential Health Benefits. Am Fam Phy 2009;79 (7):591-594.

10. Abdel-Tawwab M, Ahmad MH and Sakr SFM. Use of Green Tea, Camellia sinensis L., in Practical Diet for Growth and Protection of Nile Tilapia, Oreochromis Niloticus (L.), against Aeromonas hydrophila Infection. J World Aqu Soc 2010;41: 203213.

11. Kim YB, Kim YC, Lee LS and Kim SH. Quantitative analysis of major constituents in green tea with different plucking periods and their antioxidant activity. Molecules 2014;19 (7):91739186.

12. Juneja LR, Kapoor MP, Okubo T and Rao TP. Green tea polyphenols: nutraceuticals of modern life. Boca Raton: CRC 2016;348.

13. Anand J et. al. Green Tea Enhances Nutritional and Antioxidant Potential of Pearl Millet Based Cookies: A Healthy Approach. Int J Curr Res Rev 2020;12(18):48-54.

14. Benelli R, Morini M, Albini A, Garbisa S, Dona M, Dell'Aica I, Calabrese $\mathrm{F}$ et al. Neutrophil restraint by green tea: inhibition of inflammation, associated angiogenesis, and pulmonary fibrosis. J Immunol 2003;170(8):4335-4341.
15. Youdim MBH, Mandel S, Amit T and Weinreb O. Neurological mechanisms of green tea polyphenols in Alzheimer's and Parkinson's diseases. J Nutr Biochem 2004;15(9):506-516.

16. Yang CS, Hong J and Annu. Prevention of chronic diseases by tea: Possible mechanisms and human relevance. Rev Nutr 2013;17:161-181.

17. Whelan AM, Killian L, Jurgens TM, Doucette S, Kirk S and Foy E. Green tea for weight loss and weight maintenance in overweight or obese adults. Cochrane Database Syst Rev 2012;12.

18. Walsh DA and Pearson CI. Angiogenesis in the pathogenesis of inflammatory joint and lung diseases. Arthr Res 2001;3(3):147153.

19. Ščerbová J, Kandričáková A, Hamarová L' and Lauková A. Relation to enterocins and herbal extracts of fecal hemolytic Escherichia coli from domestic ducks detected with MALDI-TOF mass spectrometry. Poultry Sci 2019;98(11):5925-5931.

20. Dkhil MA, Zreiq R, Hafiz TA, Mubaraki MA, Sulaiman S, Algahtani F, Abdel-Gabera R, Al-Shaebi EM, SalehAl-Quraishy, et al. Anthelmintic and antimicrobial activity of Indigofera oblongifolia leaf extracts. Saudi J Bio Sci 2020;27(2):594-598.

\section{Table 1: The Phytochemical constituents of Camellia sinensis}

\begin{tabular}{lc} 
PHYTOCHEMICAL CONSTITUENTS & PRESENCE \\
Proteins & + \\
Tannins and Phenols & + \\
Glycosides & + \\
Saponins & + \\
Flavonoids & + \\
Triterpenoids & - \\
Phlobatannin & + \\
Alkaloids & + \\
Lipids & + \\
Steroids & - \\
Terpenoids & \\
\hline
\end{tabular}

(+present, - absent)

Table 2: GC-MS analysis result for major phytocomponents in Camellia sinensis extract

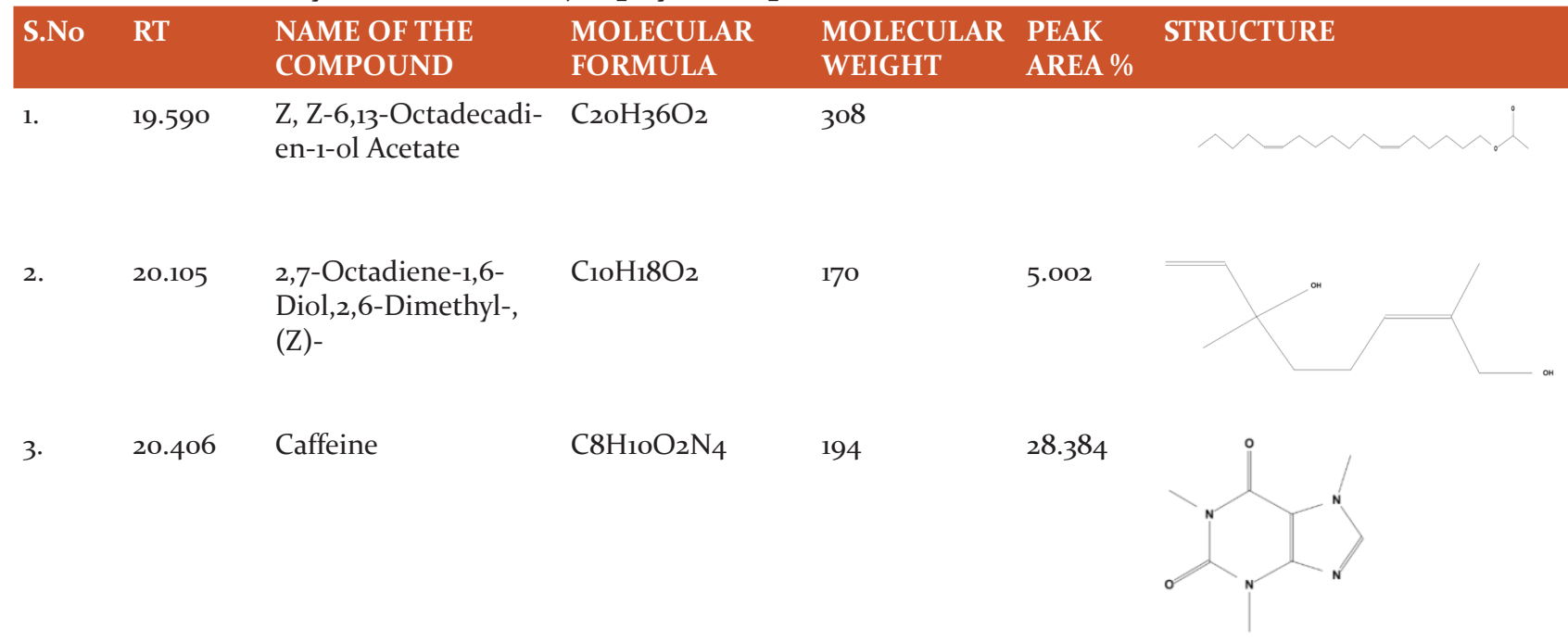


Table 2: (Continued)

\begin{tabular}{|c|c|c|c|c|c|c|}
\hline S.No & RT & $\begin{array}{l}\text { NAME OF THE } \\
\text { COMPOUND }\end{array}$ & $\begin{array}{l}\text { MOLECULAR } \\
\text { FORMULA }\end{array}$ & $\begin{array}{l}\text { MOLECULAR } \\
\text { WEIGHT }\end{array}$ & $\begin{array}{l}\text { PEAK } \\
\text { AREA \% }\end{array}$ & STRUCTURE \\
\hline 4. & 21.001 & $\begin{array}{l}\text { Bicyclo [4.1.o] } \\
\text { Heptane, } 7 \text {-Pentyl- }\end{array}$ & $\mathrm{C}_{12} \mathrm{H}_{22}$ & 166 & 61.629 & \\
\hline 5. & 22.281 & $\begin{array}{l}\text { 6,8-Dodecadien- } \\
\text { 1-ol }(6 \mathrm{Z}, 8 \mathrm{E})\end{array}$ & $\mathrm{C}_{12} \mathrm{H}_{22}$ & 166 & 1.242 & \\
\hline 6. & 26.513 & $\begin{array}{l}\text { 6,11-Undecadiene,1- } \\
\text { Acetoxy-3,7-Dime- } \\
\text { thyl- }\end{array}$ & $\mathrm{C}_{14} \mathrm{H}_{24} \mathrm{O}$ & 208 & 1.456 & \\
\hline 7. & 27.479 & $\begin{array}{l}\text { 1,9-Nonanediol, } \\
\text { Dimethanesulfonate }\end{array}$ & $\mathrm{C}_{11} \mathrm{H}_{24} \mathrm{O}_{6} \mathrm{~S}_{2}$ & 316 & 2.287 & \\
\hline
\end{tabular}

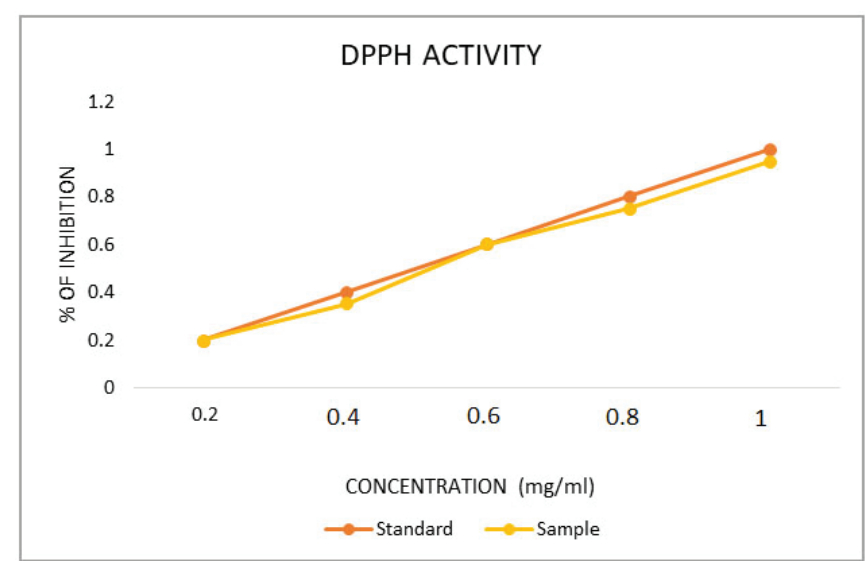

Figure 1: The below graph is provided with the IC50 values for both the standard (ascorbic acid) and sample (floral extract).

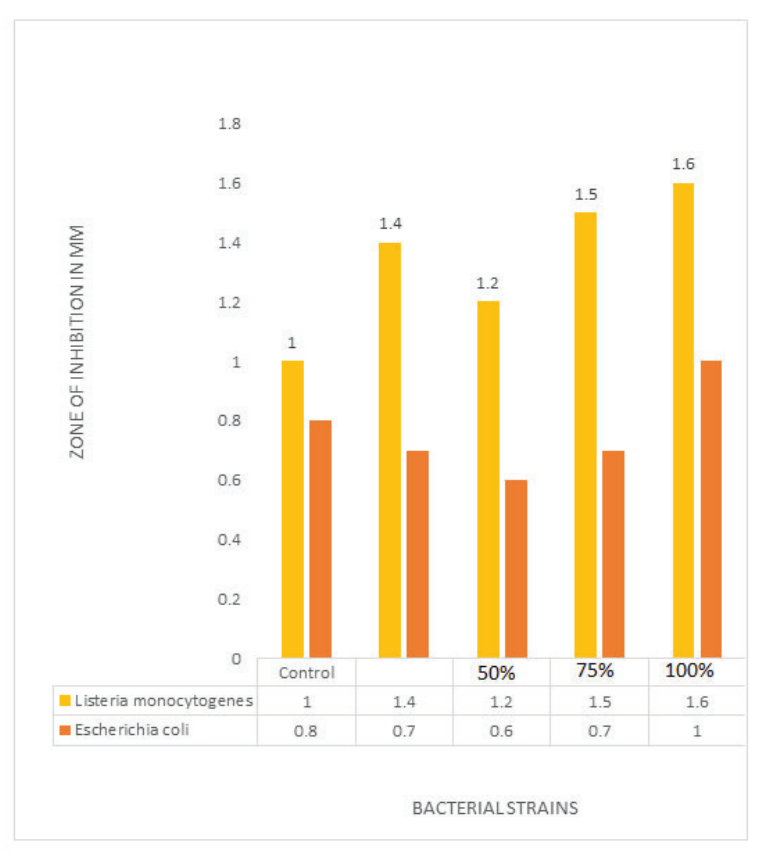

Figure 2: The zone of inhibitions of bacterial species are shown in the below graph. 


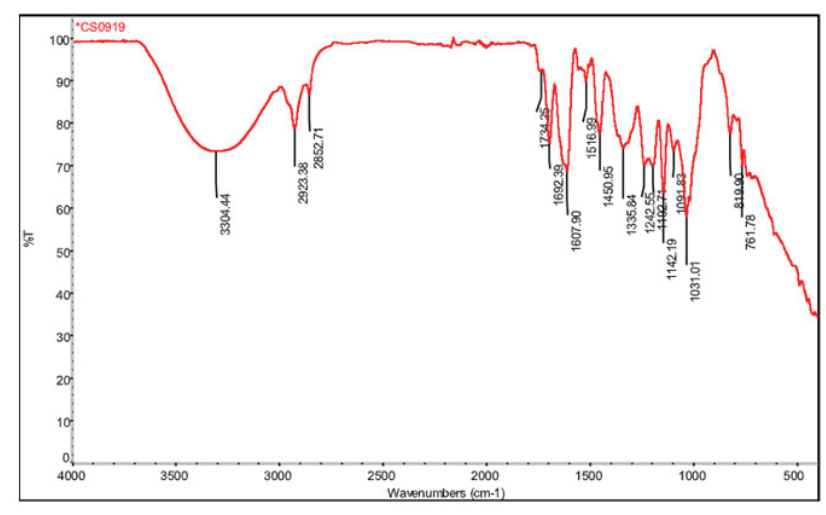

Figure 3: The structural compounds present in the extract which were predicted by using FTIR analysis is shown in the graph.

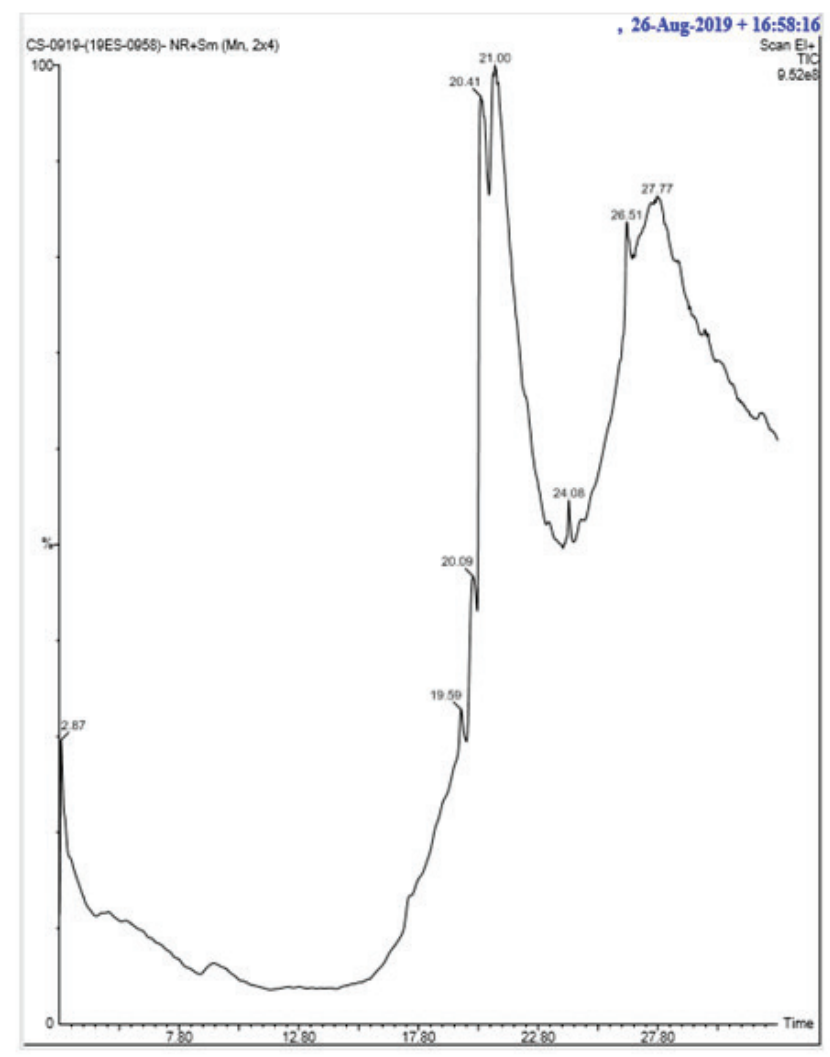

Figure 4: The chromatogram of compounds present in Came/lia sinensis.

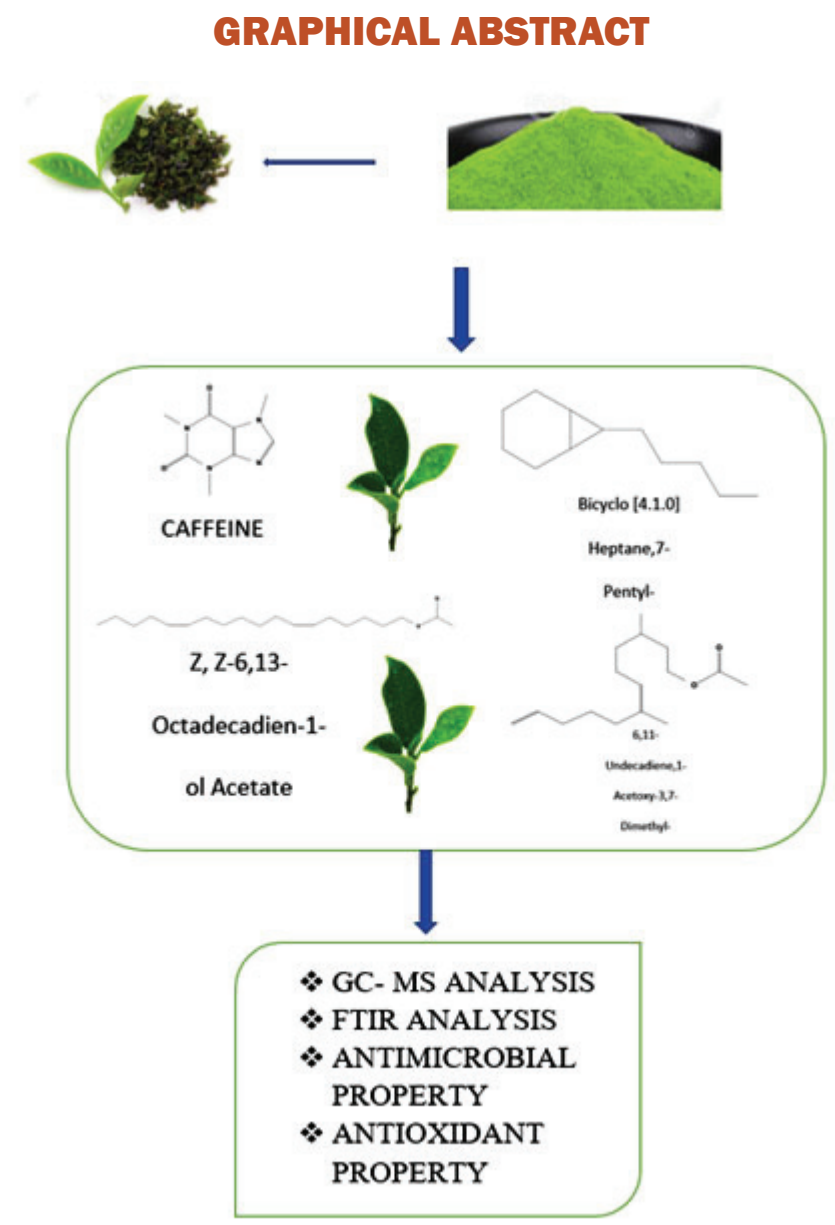

GRAPHICAL ABSTRACT

ANTIOXIDANT

PROPERTY 